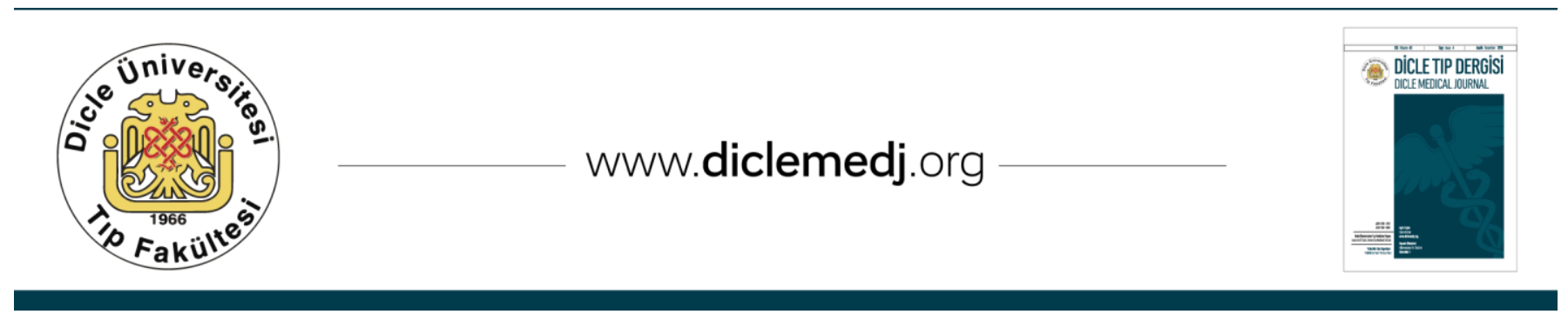

Derleme / Review

\title{
INH Direnç Mekanizmaları
}

\author{
Tanseli Gönlügür1, Ugur Gönlügür² \\ 1 Çanakkale Devlet Hastanesi Göğüs Hastalıkları Abd. Çanakkale, Türkiye ORCID: 0000-0003-0751-6184 \\ 2 Çanakkale 18 Mart Üniversitesi Göğüs Hastalıkları Abd. Çanakkale, Türkiye ORCID: 0000-0001-8720-2788
}

Geliş: 30.06.2017 Revizyon: 09.08.2017 Kabul: 21.08.2017

\section{Özet}

Her ne kadar izoniazid (INH) 'ın Mycobacterium tuberculosis üzerindeki etki mekanizması tam anlaşılamamış olsa da öncü ilaç olan INH sitoplazmaya pasif difüzyon ile girmektedir. KatG geni tarafından kodlanan katalaz/peroksidaz enzimi ile aktiflenmektedir. INH 'in aktiflenmesi ile serbest metabolik radikaller oluşmakta, bunlar da mikolik asit sentezi gibi pek çok hücresel fonksiyonu bozmaktadırlar. KatG mutasyonları INH direncinin ana sebebidir. INH 'a dirençli klinik izolatların \% 50 'den fazlasında katG 315. pozisyonda serin yerine treonin 'in değiştiği bir mutasyon vardır. İnhA, ndh ve pompa genleri gibi genler de INH direncine katkıda bulunabilirler. Bu derleme yazısı Mycobacterium tuberculosis 'de INH etki mekanizmasını ve ilaç direncinin moleküler temellerini özetlemektedir.

Anahtar kelimeler: İzoniazid, direnç, mekanizma, tüberküloz, tedavi

\section{INH Resistance Mechanisms}

\begin{abstract}
Although the precise mechanism of isoniazid (INH) action on Mycobacterium tuberculosis remains poorly understood, the pro-drug INH enters the cytoplasm through simple passive diffusion. It activated by the enzyme catalase/peroxidase encoded by KatG gene. Activation of INH results in the formation of various potent free radical species that are capable of disabling many cellular processes such as mycolic acid synthesis. Mutations in katG are the major mechanism of INH resistance. More than $50 \%$ of isoniazid-resistant clinical isolates contain a mutation in KatG wherein the serine at position 315 is substituted with threonine. Several other genes such as inhA, ndh, and efflux pump genes may contribute to INH resistance. This review article discusses the mechanisms of action of INH and the molecular basis of drug resistance in $\mathrm{M}$. tuberculosis.
\end{abstract}

Keywords: Isoniazid, resistance, mechanisms, tuberculosis, treatment

DOI: $10.5798 /$ dicletip.339020

Yazışma Adresi / Correspondence: Ugur Gönlügür, Çanakkale 18 Mart Üniversitesi Göğüs Hastalıkları Abd. Çanakkale, Türkiye e-mail: gonlugur@gmail.com 


\section{GİRIŞ}

İzoniazid (INH) hem aktif tüberkülozun tedavisinde hem de latent enfeksiyonun tedavisinde kullanılan bir ajandır. Hem MDR (Multidrug resistance, basilin INH ve rifampine dirençli olması) hem de XDR (Extensively drug resistance, MDR özellik taşıyan basilin bir fluorokinolon ve enjektabl 3 ilaç olan amikasin, kapreomisin veya kanamisinden birine daha dirençli olması) tanımlarında INH direnci kriter alınan bir parametredir. Tekli direnç olarak sadece INH direnci gösterenlerde prognozun daha kötü olduğu da bildirilmektedir ${ }^{1}$. Bu nedenlerle bu yazımızda INH direnç mekanizmalarını incelemek istedik.

İzonikotinik asid hidrazid (INH) sentetik bakterisidal bir ajan olup Mycobacterium tuberculosis complex üyeleri dışındaki mikroorganizmların nerdeyse tümüne karşı etkisizdir². İlk kez 1912 'de 2 çek bilim adamı tarafından sentezlenmiş (3) olmakla beraber 1952 'den sonra tüberküloz tedavisinde kullanılmıştır ${ }^{1}$. Dar spektrumu nedeniyle ideal bir antitüberküloz ilaç olmuştur. INH ilk 24 saat bakteriyostatik daha sonraki maruziyetlerde bakterisit etki gösterir ${ }^{1}$.

\section{KatG}

Diğer bakterilerde kazanılmış antibiyotik direnci mobil genetik elementlerin (plazmid, transpozon, integron) transferi yoluyla gerçekleşse de mikobakterilerde kromozom genlerinde mutasyon ile gerçekleşmektedir ${ }^{4}$. $\mathrm{Bu}$ mutasyonlar da klasik olarak suboptimal tedavinin bir sonucudur. INH direncinin en sik nedeni KatG mutasyonlarıdır ${ }^{5}$. KatG geni 80 kilodalton ağırlı̆̆ında HEM içeren 744 aminoasit içeren bir protein kodlar ${ }^{1}$. KatG enzimi çok fonksiyonlu bir katalaz/peroksidaz enzimi olup peroksinitritaz ve NADH oksidaz aktiviteleri de sergilemektedir. Peroksinitritaz özelliği sayesinde bakteri reaktif nitrojen metabolitlerini nötralize edebilmektedir ${ }^{1}$. Mikobakteride bulunan bu enzimin görevi konakçı fagositinde bulunan NADP oksidaz tarafından üretilen peroksitleri nötralize etmektir ${ }^{6}$. Dolayısıyla insan makrofajlarının oksidatif saldırılarına karşı mikobakterinin en önemli savunma silahıdır.

\section{INH öncü ilaç olup katG tarafindan aktive edilmektedir}

Duyarlı M.tuberculosis suşlarında INH için MIC değeri 0.02-0.05 mikrogram/ml 'den düşüktür7. KatG geninin delesyona tabi tutulması M.tuberculosis 'de INH 'in MIC değerini 50 mikrogram $/ \mathrm{ml}$ düzeyinin üstüne çıkarmaktadır. Bu da INH etkinliği için KatG geninin ürettiği katalaz-peroksidaz enziminin önemini ortaya koymaktadır ${ }^{2} .1954$ yılında Middlebrook ve arkadaşları INH 'a direnç kazanan suşlarda katalaz aktivitesinin düștüğünü bildirmiștir8.

\section{KatG 'nin kodladiğı enzim INH 'dan reaktif metabolitler üretmektedir}

INH piridin halkası ve hidrazid grubu içeren bir molekül olup (Resim 1) hücreye pasif difüzyonla girince Mycobacterium üzerinde bulunan KatG tarafindan aktif metabolitlerine (süperoksit, hidrojen peroksit, alkil hidroperoksit, nitrik oksit gibi) dönüştürülür. Hidrazid nitrojenin oksidasyonu ile süperoksit anyonu oluşmaktadır ${ }^{1}$. Nitrik oksit ve süperoksid anyonu tepkimeye girerlerse peroksinitrit gibi bir reaktif nitrojen metaboliti oluşmaktadır. Oksijen, nitrojen veya karbon molekülü içeren reaktif metabolitler (izonikotinoil radikal gibi) hücrede gerek $\mathrm{NAD}(+)$ gerekse NADP(+) 'ye irreversibl bağlanırlar. INH-NADP kompleksinin Mycobacterium tuberculosis 'de dihidrofolat redüktaz genine bağlanarak nükleik asit sentezini bozabileceği de gösterilmiştir 6 . 
<smiles>NNC(=O)c1ccncc1</smiles>

isoniazid

(INH)

Resim: INH moleküler yapısı

\section{INH direncinin en sik nedeni katG mutasyonlarıdır}

KatG enzimi defektif olduğunda INH'ı aktif metabolitlerine dönüştüremez. Bakteride katG enzimi varsa oksidanlara karşı kendini savunabilir ama INH 'a karşı da savunmasız olmak zorunda kalmaktadır. Ancak gerçek hayatta "ya hep ya hiç" kuralı yoktur. KatG aktivitesini tamamen ortadan kaldıran bir mutasyon mikobakterinin virülansını yitirmesine neden olabileceğinden ${ }^{9} \quad$ KatG mutasyonlarında enzim (katalaz/peroksidaz) aktivitesi düşük düzeye inmekte ama tamamen ortadan kalkmamaktadır ${ }^{10}$. KatG mutasyonlarında enzim aktivitesi \%30-40 düzeyine düşmekle beraber mikroorganizmanın virülans göstermesi için yeterli bir düzey sağlamaktadır ${ }^{11}$. Klinikte INH rezistansı gösteren pek çok suşta KatG geni vardır². KatG mutasyon sıklı̆̆ Türkiye'de $\% 77$ bulunmuștur ${ }^{12}$. $\mathrm{Bu}$ oran Amerika Birleşik Devletlerinde \%32, Kanada 'da \%45, İspanya'da \%61 'dir11. INH dirençli klinik izolatların \%50-95 'inde KatG S315 mutasyonu görülmektedir ${ }^{10}$. Bu mutasyonda 315. kodondaki serin aminoasidinin yerini Treonin aminoasidi almıştır. $\mathrm{Bu}$ durumda enzimin katalaz aktivitesi 6 kat azalmakla beraber peroksidaz aktivitesi ancak yarı düzeyine inmektedir ${ }^{2}$. Bangladeş'te INH dirençli suşların \%84 ünde KatG geni 315 kodon mutasyonu saptanmıştır ${ }^{11}$. KatG S315 mutasyonunda yapılan ultrastrüktürel çalışmalar INH 'ın geçmesi gereken HEM ulaşım kanalı çapının $6^{\circ} \mathrm{A}$ 'dan $4.7^{\circ} \mathrm{A}$ 'a düştüğünü göstermiştir. Bununla beraber INH 'ın yine de enzimin katalitik merkezine ulaşabildiği ama zemindeki mutasyon nedeniyle INH 'In bağlanacağı bölgedeki fazlalık metil grubu nedeniyle substrat spesifitesini yitirdiği ifade edilmektedir ${ }^{10}$. Mycobacterium bovis suşlarının çoğunda doğal olarak KatG geni 463. kodondaki arjinin yerine lösin vardır. Bu nedenle M.bovis 'in M.tuberculosis'e göre INH 'a nispeten daha az duyarlıdır. Ancak bu mutasyon enzimin katalaz-peroksidaz aktivitesini değiştirmemektedir².

\section{KatG ekspresyonunun kontrolü}

Bakteriler hidrojen peroksit gibi oksidanlara maruz kaldıklarında oxyR geninin ürettiği Oxyr proteini, KatG ve ahpC gibi antioksidan proteinleri üreten genleri aktiflemektedir. Mikobakterilerde oxyR geni inaktifdir. Dolayısıyla oksidanlara karşı hassasiyetleri vardır. AhpC geni alkil hidroperoksid redüktaz enziminin küçük subünitini sentezlemektedir². KatG aktivitesinin azalmasının yarattığ (peroksit gibi) oksidanlara karşı savunma defekti başka bir enzim ile kompanze edilmeye çalışılır. $\mathrm{Bu}$ enzim ahpC geni tarafından kodlanan alkil hidroperoksidaz redüktaz enzimidir ${ }^{9}$. Mycobacterium tuberculosis'de katG gen ekspresyonu konusunda fazla bilgi olmasa da furA (Ferric uptake regulator) geni katG ekspresyonunu baskılamaktadır ${ }^{1}$. Bunun tersine furA 'nın baskılanması da katG ekspresyonunu arttırmaktadır.

\section{INH 'a bağlı olarak mikolik asit sentezinin bozulması}

Mikolik asit ise mikobakteri hücre duvarında yer alan 70-90 karbonlu çok uzun zincirli bir lipiddir. INH mikolik asit sentezini bozduğu için bakterinin aside olan direncini bozmaktadır ${ }^{1}$. INH tedavisi ile Mcobacterium tuberculosis'in asidorezistan boyanma özelliğini yitirdiği 1953 yılında gözlenmiştir. Mikobakteride mikolik 
asid gibi yağ asitlerinin sentezi açil grubunu birbirlerine transfer ederek büyüten 4 enzimli bir döngüde gerçekleşmektedir. Bunlar sırasıyla enoil-ACP redüktaz $\rightarrow$ beta-ketoaçil ACP sentaz $\rightarrow$ beta-ketoaçil ACP redüktaz $\rightarrow$ beta-hidroksi açil ACP dehidrataz adlı enzimlerdir.

$\mathrm{Bu}$ döngünün durması mikobakteri içinde uzun zincirli (24-26 karbonlu) doymuş yağ asitlerinin sitoplazmada birikmesine neden olmaktadır ${ }^{13}$.

INH 'in açil piridin parçasının NADH 'ye C4 pozisyonunda kovalan bağla bağlandığı in vitro olarak gösterilmiștir ${ }^{2}$. Bu ikili kompleks ise enoil ACP (acyl carrier protein, açil taşıyıcı protein) redüktaz (InhA genince kodlanır) 'a sıkıca bağlanarak üçlü kompleks oluşturur ${ }^{1}$. Bu mekanizma ile INH kaynaklı radikaller mikolik asit sentezini bozarlar. KatG mutasyonlarından sonra INH direncinin en sık sebebi inhA aşırı ekspresyonudur. INH direnci gösteren suşların \%15-35 kadarında inhA düzenleyici bölge mutasyonları saptanmaktadır ${ }^{11}$. İnhA protein ekspresyonunun artması INH açısından hedeflerin çoğalması anlamına geleceğinden yarışmalı bir mekanizma ile INH direnci oluşmaktadır². İnhA protein ürününün NAD 'ın bağlandığı yerdeki aminoasid yapısının değişmesi INH direnci kazandırabilmektedir². Bununla beraber KatG mutasyonları yüsek düzeyde INH direnci (MIC > 1 mikrogram/ml) yaparken InhA mutasyonları hafif derecede direnç oluşturmaktadır. Ancak InhA mutasyonu etiyonamide çapraz dirence neden olabilmektedir (5). Çünkü etiyonamid kimyasal olarak isoniazide benzer bir yapısı vardır7.

$\mathrm{NAD}(+)$ düzeyi düşük olan mikobakterilerin INH 'ya dirence yol açabileceği gösterilmiştir. Dolayısıyla NADH/NAD(+) oranını etkileyen NADH dehidrogenaz gen (ndh) mutasyonları da direçten sorumlu olabilir. NADH dehidrogenaz enzimi NADH 'yi $\mathrm{NAD(+)}$ 'ya dönüştürür. $\mathrm{Bu}$ enzimde defekt olursa biriken NADH, INH-NAD ikili kompleksinin enoil açil taşıyıcı protein redüktaza bağlanmasını yarışmalı olarak engeller ${ }^{4}$.

KasA geni beta-ketoaçil açil taşıyıcı protein (ACP, acyl carrier protein) sentaz enzimini kodlamaktadır ${ }^{13}$. Mikobakteri kasA geninde aşırı ekspresyonu tetiklemesine rağmen ölmektedir. INH 'dan oluşan reaktif metabolitler NAD gibi $\mathrm{NADP}(+)$ 'ya da bağlanabilmektedir. INH metabolitinin bağlandığı NADP ise beta-ketoaçil ACP redüktazı inhibe etmektedir ${ }^{2,6}$.

Topikal dezenfektan olarak kullanılan Triclosan enoil redüktaz enzimlerini inhibe etmektedir ${ }^{14}$. Mycobacterium smegmatis triclosan 'a dirençli ise INH 'a da güçlü bir direnç göstermektedir. Oysa triclosan'a dirençli M.tuberculosis INH ‘a zaylf direnç göstermektedir. INH tedavisi M.tuberculosis'de kasA ekspresyonunu arttırmakta iken triclosan böyle bir etki göstermemektedir. Dolayısıyla inhA inhibisyonunun nasıl INH direncine yol açtığı tartışmalıdır. Ancak INH duyarlı suşlarda inhA ve kasA mutasyonları gözlenmemektedir.

M.smegmatis her 2 saatte hücre duvarını yenilemektedir. Oysa M.tuberculosis'de hücre duvarı örmek 18-24 saat almaktadır. M.smegmatis ve M.avium 'da mikolik asit sentezinin hayati önemi yoktur. Oysa INH 'a maruz kalan M.tuberculosis'de mikolik asit sentezinin bozulması ile hücre ölümü beraberlik göstermektedir. In vitro şartlarda besi ortam sıcaklığının $20{ }^{\circ} \mathrm{C}$ 'ye düşürülmesi M.tuberculosis'den INH maruziyetinin yaptığ etkilerin benzerlerini göstermektedir ${ }^{14}$. Bu da INH tedavisinin bakteriyi mikolik asit sentezini inhibe ederek öldürmekten ziyade hücre içi proteinleri inaktive ederek mikolik asit sentezi gibi hayati fonksiyonları bozduğunu düşündürmektedir.

\section{INH dorman basillere etkili değildir}

INH sadece çoğalan bakterilere etkilidir. Dorman veya anaerobik metabolizma yapmak zorunda kalan M.tuberculosis complex üyeleri 
üzerinde etkisi yoktur ${ }^{1}$. Dorman basiller latent enfeksiyonda ve tüberküloz nükslerinde önemlidir. Latent enfeksiyonda tüberküloz basilleri makrofaj içinde fagozomun lizozom ile füzyonunu engelleyerek hayatını intrasellüler olarak idame ettirmektedir ${ }^{15}$. DosR (dormancy transcriptional regulator) geninin M.tuberculosis'i dorman hale dönüşmesinde görevli olduğu düşünülmektedir ${ }^{4}$. Dorman basiller mikobakteriyel DNA bağlayıcı protein 1 (MDP1) adı verilen histon benzeri protein KatG transkripsiyonunu azaltmaktadır 5 .

İn vitro şartlarda Mycobacterium tuberculosis üç yolla dorman haline getirilebilmektedir Birinci yol parsiyel oksijen basıncının düşürülmesi ile ${ }^{16}$, ikinci yol besin kısıtlaması ile 17 üçüncü yol ise nitrik oksit maruziyeti iledir ${ }^{18}$. Nitrik oksit bakterilerde ve mitokondride aerobik solunumu inhibe etmektedir. Dorman bakteride DNA, RNA ve protein düzeyleri minimum düzeye inmekte, çoğalma mekanizması durmakta ve antimikrobiyal maddeler için bir bakıma hedef azaltımına gidilmektedir. Dorman hale dönüșen mikobakteride INH ve rifampisin direnci artmaktadir.

Mikobakterinin dorman forma dönmesinde bir önemli faktör L,D transpeptidaz (Ldt) enzimleridir ${ }^{19}$. Bu enzimler normal şartlarda görev yapan $D, D$ transpeptidaz enzimleri gibi peptidoglikan sentezinin son aşamalarında görevlidirler. Peptidoglikan yapısındaki 4-3 çapraz bağlarının yerini 3-3 çapraz bağları almaktadır.

\section{INH 'in inaktivasyonu}

Nat geni tarafından üretilen Arilamin-N-açetil transferaz enzimi INH molekülünü asetilasyon mekanizması ile inaktive etmektedir ${ }^{20}$. Sitoplazmada bulunan arilamin-N-açetil transferaz enzimi asetil koenzim A'dan aldığ asetil grubunu substrat olarak gördüğü bir moleküle yapıştırmaktadır ${ }^{9}$. Mycobacterium bovis'de bu enzim hücre duvarı sentezinde de görevlidir. İnsanda bulunan NAT2 enzimi de
INH 'ı inaktive etmektedir. Ancak INH 'ı yavaş asetile eden kişiler INH aracılı toksisiteye (nörotoksisite veya hepatotoksisite) daha eğilimlidirler. Bunun tersine hızlı asetile edenlerde ise INH dozu yetersiz kalabilir. Kafkas ırkına göre Japon ırkında hızlı asetile edici birey sıklığı daha fazladır ${ }^{1}$.

\section{INH için diğer direnç mekanizmaları}

Gram-negatif bakteriler ile kıyaslandığında mikobakteri hücre membranı suda çözünen bileşiklere karşı daha az geçirgendir. Mikobakteri hücre duvarında yer alan pompalar INH dişında rifampisin, etambutol, streptomisin gibi antibiyotikleri hücre dışına atmaktadır ${ }^{4}$. INH direnci saptanmış bir klinik mikobakteri izolatında INH direncini sağlayacak bir gen mutasyonu yoksa pompa genlerinin incelenmesi uygundur. Rezerpin veya verapamil gibi ajanlarla pompalar inhibe edilebilmektedir.

Az bir kısım olguda iniA, iniB, iniC genleri INH direncinden sorumlu olabilir ${ }^{21}$. Bu genler INH tedavisi ile indüklenen genlerdir. Rifampisin, INH veya streptomisine maruz kalan Mycobacterium tuberculosis'de trisiklik asit döngüsündeki izositrat liyaz enzim ekspresyonları tetiklenir. Bu enzimi ekspresse etmeyen suşların antibiyotiklere 100 kat daha hassas oldukları ama antioksidan konulunca hassasiyetlerinin ortadan kalktığ görülmüștür ${ }^{22}$.

\section{KAYNAKLAR}

1. Unissa AN, Subbian S, Hanna LE, Selvakumar N. Overview on mechanisms of isoniazid action and resistance in Mycobacterium tuberculosis. Infect Genet Evol. 2016; 45:474-92.

2. Ramaswamy S, Musser JM. Molecular genetic basis of antimicrobial agent resistance in Mycobacterium tuberculosis: 1998 update. Tuber Lung Dis. 1998; 79:329.

3. Heym B, Saint-Joanis B, Cole ST. The molecular basis of isoniazid resistance in Mycobacterium tuberculosis. Tuber Lung Dis. 1999; 79:267-71. 
4. Nasiri MJ, Haeili M, Ghazi M, et al. New Insights in to the Intrinsic and Acquired Drug Resistance Mechanisms in Mycobacteria. Front Microbiol. 2017; 8:681.

5. Zhang Y, Yew WW. Mechanisms of drug resistance in Mycobacterium tuberculosis: update 2015. Int J Tuberc Lung Dis. 2015; 19:1276-89.

6. Timmins GS, Deretic V. Mechanisms of action of isoniazid. Mol Microbiol. 2006; 62:1220-7.

7. Musser JM. Antimicrobial agent resistance in mycobacteria: molecular genetic insights. Clin Microbiol Rev. 1995; 8:496-514.

8. Cohn ML, Kovitz C, Oda U, Middlebrook G. Studies on isoniazid and tubercle bacilli. II. The growth requirements, catalase activities, and pathogenic properties of isoniazid-resistant mutants. Am Rev Tuberc. 1954; 70:641-64.

9. Almeida Da Silva PE, Palomino JC. Molecular basis and mechanisms of drug resistance in Mycobacterium tuberculosis: classical and new drugs. J Antimicrob Chemother. 2011; 66:1417-30.

10. Cade CE, Dlouhy AC, Medzihradszky KF, et al. Isoniazid-resistance conferring mutations in Mycobacterium tuberculosis KatG: catalase, peroxidase, and INH-NADH adduct formation activities. Protein Sci. 2010; 19:458-74.

11. Rahim Z, Nakajima C, Raqib R, Zaman K, Endtz HP, van der Zanden AG, Suzuki Y. Molecular mechanism of rifampicin and isoniazid resistance in Mycobacterium tuberculosis from Bangladesh. Tuberculosis (Edinb). 2012; 92:529-34.

12. Aslan G, Tezcan S, Serin MS, Emekdas G. Genotypic analysis of isoniazid and rifampin resistance in drugresistant clinical Mycobacterium tuberculosis complex isolates in southern Turkey. Jpn J Infect Dis. 2008; 61:255-60.

13. Barry CE 3rd, Slayden RA, Mdluli K. Mechanisms of isoniazid resistance in Mycobacterium tuberculosis. Drug Resist Updat. 1998;1: 128-34.
14. Slayden RA, Barry CE 3rd. The genetics and biochemistry of isoniazid resistance in mycobacterium tuberculosis. Microbes Infect. 2000;2: 659-69.

15. Pinheiro M, Silva AS, Pisco S, Reis S. Interactions of isoniazid with membrane models: implications for drug mechanism of action. Chem Phys Lipids. 2014;183:18490.

16. Wayne LG, Hayes LG. An in vitro model for sequential study of shiftdown of Mycobacterium tuberculosis through two stages of nonreplicating persistence. Infect Immun. 1996; 64:2062-9.

17. Betts JC, Lukey PT, Robb LC, et al. Evaluation of a nutrient starvation model of Mycobacterium tuberculosis persistence by gene and protein expression profiling. Mol Microbiol. 2002; 43:717-31.

18. Voskuil MI, Schnappinger D, Visconti KC, et al. Inhibition of respiration by nitric oxide induces a Mycobacterium tuberculosis dormancy program. J Exp Med. 2003; 198:705-13.

19. Lavollay M, Arthur M, Fourgeaud M, et al. The peptidoglycan of stationary-phase Mycobacterium tuberculosis predominantly contains cross-links generated by L,D-transpeptidation. J Bacteriol. 2008; 190:4360-6.

20. Ramos RM, Perez JM, Baptista LA, de Amorim HL. Interaction of wild type, G68R and L125M isoforms of the arylamine-N-acetyltransferase from Mycobacterium tuberculosis with isoniazid: a computational study on a new possible mechanism ofresistance. J Mol Model. 2012;18:4013-24.

21. Zhang M, Yue J, Yang YP, et al. Detection of mutations associated with isoniazid resistance in Mycobacterium tuberculosis isolates from China. J Clin Microbiol. 2005; 43:5477-82.

22. Nandakumar $M$, Nathan $C$, Rhee KY. Isocitrate lyase mediates broad antibiotic tolerance in Mycobacterium tuberculosis. Nat Commun. 2014; 5:4306. 